\title{
The Cultural Genetics of the Aḥmadiyya Muslim Jamā'at
}

\author{
M. Afzal Upal
}

\section{1 \\ Introduction}

Aḥmadiyya Muslim Jamācat was founded as a movement to reform Islam by Mirzā Ghulām Aḥmad (1839-19o8) in Qāọiān, Punjab, India in 1889. Following Ahmad's death, the movement was led by one of his most senior disciples Hakim Nūr al-Dīn (1841-1914). Nūr al-Dīn called himself the khaliffa. After his death, the movement split into two factions. The larger faction stayed in Qādiān and was led by Aḥmad's son Mirzā Bashiruddin Mahmud Aḥmad (1889-1965), who was considered the second Khalifa by his followers. The smaller faction moved to Lahore and disbanded the office of Khalifa altogether. Following the partition of British India, the second Khalifa moved the Jamā'at headquarter to Rabwah, Pakistan in 1948. After Mahmud Aḥmad's death, his eldest son, Mirzā Nasir Ahmad (1909-1982) took the reins of the main faction as Jamā'at's third Khalifa. In 1974, the parliament amended Pakistan's constitution to declare that anyone who believes in Mirzā Ghulām Aḥmad as a divinely appointed Messiah is not a Muslim. Nasir Aḥmad's younger brother, Mirzā Tahir Aḥmad (19282003), became the fourth Khalifa on his passing in 1982. In April 1984, the military dictator Zia-ul-Haq issued Ordinance Xx to make it illegal for Ahmadis to preach their faith "or in any manner whatsoever outrages the religious feelings of Muslims." Days later, Tahir Ahmad escaped to London in a cloak and dagger style. After Tahir Aḥmad's passing in 2003, Mirzā Masrur Aḥmad, a great grandson of Mirzā Ghulām Aḥmad became Jamāeat's fifth Khalifa. He continues to live in UK and guide millions of his followers all around the world.

Since its inception, the movement has attracted attention from scholars (Walter 1918; Friedman 1992; Khan 2015; Lavan 1974) as well as Muslim, Christian and the Hindu faithful because of the messianic claims of its founder. Mirzā Ghulām Aḥmad claimed that he was a prophet of God and both the Islamic mahdī and the messiah of various religious traditions. Such claims drew immediate rebuke from Muslim 'ulam $\vec{a}$ ' across India who accused Ahmad of kufr-ungratefulness to God. Scholars of South Asian Islam have been at a loss to explain what led Ahmad to make such extra-ordinary claims. 
In his seminal article delineating boundaries between sects, denominations, and minority, Mark Sedgwick (2000) discusses the case of Ahmadiyya Jamā'at extensively pointing out its various "peculiarities" that make it harder to fit it neatly into any of those categories. Recently, Upal (2017) explored various connections between Ahmad and the Ahl-e-hadìth 'ulamāas, namely, Abū Sayyid Muhammad Ḥusayn Baṭālvī and his teacher Syed Nazir Hussain Dehlavi. In From Șüfism to Ahmadiyya (2015) Adil Hussein Khan traces various modern reformist, as well as traditional Ṣufi, influences on Ahmmad's thought. In particular, he suggests that Ahl-e-Ḥadìth alim or scholar the Șūfi Abdullah Ghaznavi, as well as writings of the Sunfi greats such as Shaykh Ahmad Sirhindi, may have had significant influence on Ahmad's thinking. Yohanan Friedman (1992) also explored similarities between Ahmad's spiritual claims and those of Șūfi masters such as Shaykh Ahmad Sirhindi. In this chapter, I will add a third source of influence that has not been fully explored yet, namely, that of the rationalist South Asian Muslim reformer Sir Syed Ahmad Khan (1817-1898).

The nineteenth century was a time of great tumult for South Asian Muslims, and therefore a time of great opportunity for Muslim reformers (or "social identity entrepreneurs" as I have referred to them elsewhere (Upal 2017) to emphasize the role they play in creating and marketing social identity beliefs) to remove what they perceived as non-Muslim influences from the thinking of the Muslim masses. The most influential among them were the descendants of the eighteenth century reformer Șūfi Shāh Walī Allāh (or Waliullah) of Delhi and his students at the Delhi-based Madrasa Rahimimiyya which was founded by Walī Allāh's father.

Although a sanad-holding Ṣufi himself, Shāh Walī Allāh came to believe that some Șüfi practices had become un-Islamic. He particularly objected to overly exuberant Șūfi practices such as urs celebrations of the anniversaries of dead Șüfis, revering the tombs of Șūfi masters, and asking Ṣūfis for amulets to cure various illnesses. Shāh Walī Allāh's also railed against taqlèd, that is, the traditional Sunnī Muslim practice of choosing one of the four school of $f i g h$ (Islamic jurisprudence) and exclusively following fatwās issued by scholars from that school. For most South Asian Muslims, this was the school founded by Imām Abū Haniffa, the eighth century Sunnī theologian, whose followers are known as Ḥanafìs. The remaining three schools are Mālikī, Shāfìì, and Ḥanbalī.

Shāh Walī Allāh argued that following all fatwās of one's chosen school was not mandatory on Muslims. Instead, he suggested that Muslims could pick and 
choose from fatwās of various schools and various scholars. They could even use their own reasoning faculties to carry out ijtihād (independent reasoning) in situations where no previous fatwās existed to create solutions to novel problems. Thus he argued that a Hanafí woman may disregard the edict by Abū Haniffa (who ruled that a woman whose husband goes to war and goes missing may not marry until he's confirmed dead) and remarry after waiting for four years (as Imām Mālik, founder of the Mālikī school, ruled).

Shāh Walī Allāh's sons and grandsons helped spread Shāh Walī Allāh's messages to the Madrasa Rahimiyya students and beyond. The movement they helped create came to include a broad class of Muslims. By the nineteenth century, it included much of the Muslims elite of North India who were worried about the loss of royal patronage after the demise of the Mughal power in Delhi. The Indian Muslims were divided about the best way to respond to the British occupation of India. Some declared that India had become a dar alHarb (a 'land of war'), while others insisted that it continued to be the land of peace (dar al-Islam). The proponents of the dar al-Harb enacted their beliefs and engaged in hijra (migration) to Islamic areas (including Afghanistan and Arabia). They called on their followers and other Muslims to wage jiha $\bar{d}$ against the British.

Shāh Walī Allāh's grandson Shāh Muḥammad Ishaq (1783-1846), the head of Madrasa Rahīmiyya, moved to Mecca because he believed that India had become the land of war. Another group led by Syed Ahmad Barelwī (1786-1831) moved to the tribal areas on India's north-western frontier with Afghanistan. Barelwī labeled his movement Ṭarīqa-e-Muhammadi, while others labelled them as Wahhābīs because of the similarity of their worldview to that of 'Abd al-Wahhāb of Arabia. The Wahhābīs were considered violent extremists by the British government and they came to be persecuted both in Arabia and India (Allen 2006). Barelwì's group included the younger grandson of Shāh Walī Allāh named Shāh Ismail. Both Barelwī and Ismail died in a fight with the Sikhs in 1831.

Those followers of Shāh Walī Allāh who remained in India either became completely apolitical (such as Muhammad Qasīm Nānotawī, who moved away from the limelight of Delhi to the village of Deoband, where he founded the Deobandī Movement in 1867) or they became fully supportive of British rule (Metcalfe 1982). Among the latter were Sir Syed Ahmad Khan (1817-1898), Syed Nazir Hussain (1805-1902), and Nawab Siddiq Hasan Khan (1832-189o). They called themselves variously as Muwahideen (that is, unitarians, the term preferred by Nawab Siddiq Hasan Khan), and Ahl-e-Hadith (that is, the Followers of the Prophet's Words, the term preferred by Sir Syed Ahmad Khan and Syed Nazir Hussain). Syed Nazir Hussain, a graduate of Madrasa Rahimmiyya, came to 
be known as the premier scholar and teacher of hadith in India after the departure of Shāh Muhammad Ishaq (Robinson 200o). One of Hussain's prominent students, Muḥammad Ḥusayn Bațālvī (1840-1920), was so worried about being associated with Syed Ahmad Barelwì's Wahhābì followers that he lobbied the British officials to stop referring to them as Wahhābīs. After completing his hadīth studies, Bațālvī moved back to his hometown of Batala in Punjab. In 1876, he started an Urdu magazine called Ishat-us-Sunnah to propagate the message of the Ahl-e-Hadith movement to the wider world (Robinson 1988).

Another nineteenth century group of Muslims objected to some of the teachings of the followers of the Shāh Walì Allāh movement. The Barelwīs (named after their founder Ahmed Raza Khan of Bareli [1856-1921]) defended traditional Șūfi practices. While others referred to them as Barelwīs, they called themselves 'party of the sunna' to assert that they are the true Sunnis and inheritors of the millennia and a half of the Hanafī Sunnī tradition. Barelwīs regarded Deobandīs and Ahl-e-Hadìth as innovators who disrespect traditional imams by not following all of their edicts.

\section{Syed Ahmad Khan's Rationalist Islam}

The Ahl-e-Hadith viewpoint was very influential among Delhi Muslims in the nineteenth century, including Sir Syed Ahmad Khan, the son of a noble Delhi family who became one of the most prominent Muslim reformers of the nineteenth century. Khan received a traditional training in Qurān and hadith in Delhi (some under Shāh 'Abd al-'Azīz). The Mughal Emperor Bahadur Shāh Zafar, who ruled Delhi with British support, confirmed Khan's status as a noble by awarding him titles of Javad-ud Daulah and Arif Jang in 1842 (Faruqi 2017). He helped his older brother set up Delhi's first printing press and launch the first Urdu journal. Khan claimed that Ahl-e-Hadith had been the original faith of Muslims from the very early days, but it had become corrupted after the reign of the four Sunnī Caliphs:

Mahomedanism was at first for many long years a pure and simple Theism; but in the second century of the Higra, when the ideas of the learned men as to its principle were reduced to writing, it was divided into four churches-Hanafi, Shfai, Malki, and Humbali. For some time it remained optional for Mahomedans to choose and follow any doctrine of any of these four Churches. When, however, Bani Umaiya and Bani Abbas became kings an edict was issued directing all Mahomedans to embrace the whole doctrine of any one church of the above four. Those 
who disobeyed were punished ... There were still, however, many who clung the true faith in its primitive simplicity, but who dared not breathe their opinion except to a trusted few. Their name was then Ahal-i-Hadis i.e., believers in the sayings of the Prophet, who were not bound down by the doctrines of the four churches ... In India, during the Mahomedan rule, the Turk and Pathan kings who were of the Hanafì sect were strictly averse to religious toleration, and the same state of affairs prevailed during the sovereignty of the Mogul Emperors ... On the establishment of the British rule, however, owing to the English principle of strict religious toleration, the followers of Ahal-i-Hadis again came to the front and preached openly and fearlessly.

KHAN 1872: 10-11

Thus Khan argued the Ahl-e-Hadìth view point that Indian Muslims needed to be grateful to the British for allowing them to follow their faith in freedom. Ahl-e-Hadìth also came to adopt distinct practices such as rafa-yadainrepeatedly lifting hands up to one's shoulders and dropping them to one's navel during the five daily ritual prayers - that allowed them to stand out from their fellow traditional Hanafì Muslims who made up the vast majority of Indian Muslims. Rafa-yadain, in particular, became a key marker of the Ahl-e-Hadith. In a letter Khan claimed that he had been practicing rafa-yadain long before his friend Nazir Hussain:

I am the one who turned Syed Nazir Hussain into a puritan Wahhābī. He didn't use to perform rafa-yadain during namaz [ritual Islamic prayer] even though he considered it to be the practice of those who were rightly guided. I said, this is sad that you do not practice what you consider to be a virtuous deed because of what others will think of it. He got up to offer the asar [afternoon] prayer and started practicing rafa-yadain.

KHAN 1959

Since most scholars regard Hussain to be the founder of Ahl-e-Hadìth in India, this is a remarkable statement. Khan is not only claiming to be an Ahl-e-Hadith but he is also claiming that he was an Ahl-e-Hadith even before Hussain was one. In essence he is claiming to be the real founder of the movement because he argues that he persuaded Hussain to become an Ahl-e-Hadìth and adopt the practice of rafa-yadain.

Khan's early writings mostly expressed traditional views. In his book Qaule-Matin dar ibtal-e-harkat-e-zamin (literally 'firm assertion about the false assertion of the earth's motion'), he defended the traditional Ptolemaic view 
that Sun rotated around the earth-the view that was universally accepted by early nineteenth century Indian Muslims (Powell 1993: 209). At some point early in his career, however, Khan experienced a dramatic change in his worldview. This may have been a result of deeper interactions with the increasing number of Westerners in Delhi that resulted from his decision to join the British East India Company and study at the East India Company College. Although his initial appointment was as a clerk, his talents ensured that he was quickly promoted to the rank of a jurist. Whatever caused it, Khan came to wholeheartedly adopt modern scientific views in the second half of his life. This social identity entrepreneur seems to have convinced himself that the biggest problem faced by Indian Muslims was the lack of scientific education caused by the belief that Islam was opposed to Western science. He became a forceful advocate of integration of Western science with Islamic worldview through a complete reinterpretation of over a millennium of Islamic tradition. Francis Robinson (1988) argues that Khan used the religious interpretation techniques he had learned from his Ahl-e-Hadith friends Syed Nazir Hussain and Nawab Sidiq Hasan Khan to reconcile Western science with Islam to create a distinct doctrine that is best described as a rationalist Islam.

Like the Ahl-i Hadith he circumvented the medieval law schools and went straight to the Qurān and hadìth as guidance for Muslims. The basis of his exegetical principles was that the laws of Creation were the Work of God and the Qurann was the Word of God and they just could not be contradictory — and if they seemed to be so it was because man failed to understand them correctly. So, for instance, he explained apparently miraculous events in the Qur'ān, as Christian apologists might have done similar events in the Bible, as metaphors.

ROBINSON 1988: 9

Khan has come to be so closely identified with his educational endeavours that he pursued in the second half of his life to open schools to educate Indian Muslims that his considerable intellectual efforts to reform Islam are often overlooked. Khan was in fact an alim first and foremost. He wrote a tafsir (exegesis) of the Qurān as well as several books on the topic of Islamic reform. He argued that Shāh Walī Allāh's project of ridding Islam of external influences remained unfinished because so many Muslims still held onto their superstitious beliefs. He argued that Islam was revealed as a rational religion to Prophet Muhammad and that in the intervening years, people had added irrational beliefs into Islam. He argued that Muslims had imported miracle stories from Christian and Jewish sources and also added some of their own to 
counter Christian claim that while Jesus showed miracles Muhammad did not. Extending the Ahl-e-Hadìth polemic against taqlìd, he labeled the practice of using Christian and Jewish miracle stories to interpret Qurān as taqlìd.

Khan developed a unique interpretation of the nature of God and His relationship with the universe (Derajat et al 2019). He argued that God created the universe and put the laws of nature (Qanun-e-Qudrat) in place. Just as God is unchanging so are his laws argued Khan (Bettani and Shaw 2016: 49). To imply that God changes his laws is to imply that God Himself changes which is impossible. He presented the Qur'ān's verse 48:23 — "It is the law of Allāh which hath taken course aforetime. Thou wilt not find for the law of Allāh aught of power to change" (Pickthall 1938) - as proof for his interpretation. For Khan, sunnatullah (literally 'the way of Allāh' meaning 'law of nature') is as important a divine attribute as tawhìd (unity of God) is for traditional Muslims. God's desire to maintain his law of nature trumps his desire to support his prophets and destroy their enemies through supernatural miracles. Thus, while an event may appear to be supernatural to some observers, it is in fact just an ordinary event when seen in a different light. Those who suggest that God broke his law to support His prophets do not understand the nature of God, said Khan. What these believers see as miracles that violate law of nature are really something else entirely. He wrote:

This is true that we do not completely know all the laws of nature and the ones we do know are very few and even for those we do not possess a complete knowledge. Instead our knowledge is faulty. The result is that when some strange event happens and there is plenty of evidence for its having happened and its occurrence is possibly not in accordance with known laws of nature and if we assume that there was no cheating or fraud and that it actually happened, even then we'd have to admit that there is no doubt there is a natural law that explains its occurrence that we do not yet know ... To say that the law of nature is that things happen in accordance with prayer or intention of a prophet or a holy person is not acceptable because a proof for such assertion would require that every single time that holy person prayed for something, it happens accordingly ... Shāh Waliullah has written in Hujjat-ul-Balagha Chapter Haqiqat-ul-Nabuwah wa Khwasa that miracles and acceptance of prayers are outside of prophethood.

KHAN 1885: 28-29

Khan further argued that God did not break his law of nature even to support the greatest of all prophets, namely, the prophet Muhammad. So, if God did 
not show any miracles to support Muhammad, it was unimaginable that God would have done so to support his lesser prophets. Thus, the Qurān could not be speaking of any supernatural miracles even if traditionally Muslims have understood them as such. He wrote:

Shāh Waliullah Sahib, in his book Tafhimat-e-Ilahia clearly states that there is no mention of any miracles in Qur'an. And About the splitting of the moon, he says that it was not a miracle. Thus he says that splitting-of-the-moon is not a miracle in our view. Instead, it is a sign of the Armageddon as God says that the time for the splitting of the moon comes near and Holy Prophet has informed us about it beforehand.

KHAN 1885: 7-25

The fact that Khan only turns to Shāh Walī Allāh (rather than for instance imām Abū Hanīfa-the founder of the Hanafĩ School) as he seeks authoritative voices from the past to support him shows the regard that he had for the eighteenth-century reformer. The above quoted passages also demonstrate the Ahl-e-Hadith tendency to skip over most of the medieval scholars and go to the original sources of Qurān and hadìth (sayings of the Prophet Muhammad) to bolster their arguments. Khan also invoked events from the life of Prophet Muhammad to support his argument that God does not show supernatural miracles:

The infidels demanded miracles from the Holy Prophet peace be upon him and said clearly that we will absolutely not going to believe you until you rip up the earth and draw fountains, or if you can produce flowing canals among orchards of dates and grapes, or if you drop pieces of the sky on us, or bring God and angels with you, or if you can produce a decorated house, or if you can ascend to heaven ... but despite such insistence God told his messenger, 'say to them that my Lord is pure and I'm nothing but a human being who is sent as a messenger' ... The fact that the Holy Prophet, who was the most superior of all prophets and messengers, did not have any miracles, proves that the previous prophets peace be on them also did not have any miracles.

KHAN 1885: 23-24

In a remarkable follow-up passage, Khan seems to anticipate the modern cognitive science of religion (Boyer 1994) approach to explaining the spread of religious ideas: 
If an ordinary person imprecates someone saying that lightning may fall on you' and coincidentally that person dies because of lightning. Then no one will think much of that but if that prayer were uttered by a person whose holiness fills people's hearts then it becomes associated with his miraculous powers ... Many strange rumors that have no basis in reality become popular about holy people. People are so impressed by the notion of holiness of such people that they do not research the truth and believe them without any research.

KHAN 1885: 22

It is not God or His prophets who carry out supernatural acts according to Khan, it is ordinary people engaged in ordinary processes of cognition and communication that end up creating the supernatural religious concepts.

It is not just the physical miracles such as splitting of the moon by the Prophet Muhammad that ordinary Muslims have misunderstood, argued Khan: most Muslims also misunderstand the very nature of prophethood, divine revelation, and humanity's status among the animal kingdom. Countering the traditional Sunnì belief that only prophets of God can receive God's revelation, Khan argued that ordinary human beings are not only capable of revelation but routinely receive it. Revelation is not restricted to humans either: animals can, and do, receive God's wisdom as well, claimed Khan. In his view, divine revelation is nothing but an instinctive call from one's nature:

All creation whether it be humans or animals or plants, God has put a nature into everything. Things happen according to that nature without any teacher's teachings. This blessing of nature has been labeled by some 'ulam $\bar{a}$ ' of Islam as ilhamat (revelations). But the High Lord has called it wahi ... This wahi was not delivered to the honeybee by Gabriel or another angel of God but God himself put it into it ...

According to the ranks of their nature there will be people who will be born from among them whom Shāh Waliullah Sahib has labeled as perfects, hakims, khalifas, aided by the Holy Spirit (ruh-ul-qudus) guides, imams, munazir (warners), nabī (prophets). Today's faithless people call them reformers ... A guide who has a perfect nature of guidance is a prophet $(n a b \bar{\imath})$

KHAN 1885: 16-17

Thus divine revelation is nothing but an animal's natural instincts and prophets are nothing but reformers in Khan's worldview. 
Belief in prophets is one of the six articles of faith in Islam. Traditional Sunnì Muslim doctrine not only specifies the status of prophets to be higher than that of ordinary human beings, but it also carefully delineates boundaries between different levels of prophethood and revelation. Theologians have debated differences between anbia (prophets), paighambars (messengers), and rusul (apostles), and argued in depth about what distinguishes the wahi form of revelation from those of the ilham and kashaf kind (Bisati 2001; MacGregor 2002). Khan may have been forgiven by the traditional 'ulamä' had he simply argued against these fine distinctions and insisted that all prophets were prophets and all revelation is of the same degree, but because of his wholescale reinterpretation of Islamic doctrine, he was condemned by traditional Ḥanafì 'ulam $\bar{a}^{\prime}$ (for example, Barelwīs) as a heretic. They accused him of denying the physical existence of angels, denying supernatural miracles of prophets, and even limiting God's powers. They labeled him as outside the pale of Islam and pejoratively called him a naturie (Urdu for a 'naturalist').

Given Khan's open disregard for traditional understanding of Islamic doctrine, opposition from traditional Hanafis (such as the Barelwis) was expected. However, even those who fully embraced Shāh Walī Allāh's reforms (including the Deobandīs and the Ahl-e-Hadìth) also felt that Khan had gone too far in applying his rationalism to Islamic doctrine. Both Deobandīs and Barelwīs accused Khan of being an Ahl-e-Hadìth. Ahl-e-Hadìth leaders not only denied the allegations but, as they were keen to establish themselves as genuine defenders of the faith in competition with Deobandīs and Barelwīs, they felt the need to be even harsher in their criticism of Khan. Ahl-e-Hadith leaders wanted to be seen as distant from Khan as possible. Muhammad Husayn Bațālvī said that Khan's dangerous innovations (bid'a) were so severe that he was a käfir (that is, an infidel). None of this perturbed Khan who replied that the 'ulama $\bar{a}^{\prime}$ of his time had deemed Shāh Walī Allāh as well as other reformers käfir as well. Khan continued to publish and deliver public lectures all over India. He founded the Scientific Society and Muhammadan Anglo Oriental College in Aligarh to pursue the mission of redefining Muslim social identity as that of harmony between science and Islam.

\section{Syed Ahmad Khan's Influence on Mirzā Ghulām Aḥmad}

As Khan (2015) points out, Ahmad's Ahmadi biographers are loath to admit of any external influence on his religious worldview because they regard his ideas to have been divinely inspired. Since Ahmad was repeatedly accused of plagiarizing Khan's ideas by his contemporaries early in his career (see Batalavi 
1891 for such claims made by over a dozen 'ulam $\bar{a}$ ), Ahmadis had reasons to be extra careful to minimize any mention of Khan's influence on Ahmad. Thus it is not surprising that there are only a few scattered hints of contact between Khan and Ahmad documented in the Ahmadiyya literature. During his stay in Sialkot (1864-1868), Ahmed seemed to have written a letter to Khan on hearing about Khan's plans to write an exegesis of the Bible (a first for a Muslim). It is not clear as to whether Khan responded to the young man in his twenties and if he did what he wrote. Since we also do not have access to Ahmad's letter to Khan, it is hard to see whether Khan used any of Ahmad's ideas in his exegesis. Given the status differences between the two men and the fact that Ahmad did not start proclaiming any heretical ideas till 1891 when Khan's writing career was coming to an end, it seems unlikely that any of Ahmad's writings had any impact on Khan. In the 188os when Ahmad published his first book Braheen-e-Ahmadiyya (Volume 1 was published in 1880 and Volume 4 was published in 1884), he expressed orthodox Sunnī Ahl-e-Hadìth views on most issues. Given that Khan started publishing in 1840s, and he was better known than Ahmad, we are better off searching for Khan's influence on Ahmad. We will do this by comparing Ahmad's publications published in a given year with Khan's publications published prior to that year. Such a comparison yields a number of possible instances of Khan's potential influence on Ahmad, although we have no way of knowing for sure whether Khan was the source of any of Ahmmad's ideas.

\subsection{The Nature of Revelation, Angels, and Prophecy}

Syed Ahmad Khan started publishing his rationalist ideas in 188 o through the first volume of his Qur'ānic exegesis (S.S. A. Khan, 188o). In it, argued against the notion of supernatural angels that act as mediums between God and humans (Khan 1880: 29-30, 33-34, 53-57). Instead, he said that God communicates with all human beings (and animals) at the time of their conception when he decides their nature (he probably would have used the word DNA instead of nature, had DNA been discovered by 1880 ). He endows some of his creation with stronger capabilities to receive his knowledge than others. The capabilities latent at birth become stronger as a person gets older and exercises them and they reach their full potential in God's prophets. He said, "I believe nabuwwat (that is, prophethood) to be a natural thing. A nabi (prophet) is a nabi even when he is in his mother's womb" (Khan 1880: 31). Those endowed with the knowledge to overcome their cultural norms and given the courage to seek reform are called "paighambar (messengers) in the Sharia lingo and reformers in the cultural expression" (Khan 1880: 25). The capabilities to receive divine wisdom are metaphorically referred to as the angel Gabriel in 
the Qur'ann. He wrote: "This proves that that the prophetic capability that God produced in prophets (anbia) is named Gabriel" (Khan 1880: 33), adding,

The angels that Qurān mentions cannot physically exist but the manifestations of God's infinite powers and those capabilities that God created his creation with are called angel (malak) and angels (malaika). One of them is Satan or Iblis. The rise of the mountains, water's flow, power of the trees to grow, electricity's powers of attraction and repulsion etc., all capabilities that are present in the creation are the very angels mentioned in the Qurān.

KHAN 1880: 56

Before publishing Braheen-e-Ahmdiyya, Ahmad shared his drafts with his friend and the Ahl-e-Ḥadìth alim Muḥammad Ḥusayn Bațālvī, who prominently advertised upcoming volumes of Braheen in his Ishat-us-Sunnah magazine and devoted over 150 pages to reviewing the Braheen. In his review, Bațālvī declared that it was the best defense of Islam published since the time of the Prophet Muhammad. He defended Ahmad as a good Muslim who meant well, even if he was rural and a bit over-exuberant. One of the biggest issues of contention was Ahmad's claims to be in receipt of constant communication from God in the form of dreams and ilham and wahi (revelations). While Ahmad's critics decried that Ahmad was claiming a higher status for himself by claiming to be a mulhim (receiver of divine revelations), Bațālvī defended him by saying that Ahmad was describing these experiences to impress non-Muslims by showing them that Islam's God was alive who still communicated with Muslims.

In Braheen, Ahmad expressed traditional Sunnī views about prophets, Jesus, and nature of divine revelation. However, something changed between 1884 to 1891 when Ahmad published three books in rapid succession: Fath-e-Islam, Tauzi-e-Maram, and Azala-e-Auham. In these books, Ahmad said that he no longer believed in traditional Sunnì doctrine of Jesus' ascension to heaven or the physical nature of angels. He said that the reason for this change was that Christian missionaries were duping simple Punjabi Muslims through their claims that Islamic teachings also awarded Jesus a higher status than Muhammad by allowing for Jesus' ascent to heaven while admitting a human death for Muhammad. To blunt these arguments and to restore Muhammad's superiority over Jesus, he argued that Jesus also had to die a mortal death. In order to sell others on this interpretation, Ahmad argued that many of these supernatural beliefs were, in fact, irrational and made little sense in the nineteenth century. 
Muslim researchers do not believe that angels descend on earth with their feet like humans. This idea is a false innovation because if it was necessary for angels to descend to earth with their true bodies in the service of their duties then it was impossible for any task to be completed by them. For instance, the angel of death who takes the lives of thousands of such people who are in different countries and live thousands of miles apart from each other. If he was dependent on his feet for travel to the country, city, and house of each person and then struggle to take their lives then even months are not enough for carrying out such a task.

AḤMAD 1891c: 30-31

We do not know whether Ahmad would have included Khan among the Muslim researchers. Perhaps, because of Khan's poor reputation among Ahmad's Ahl-e-Hadīth target audience, Ahmad never cites Khan in any of his writings (except when he is criticising Khan). Similar to Khan, however, Ahmad argued that instead of being physical creatures with human-like bodies, angels are natural forces:

In some places in the Holy Qur'ann, every particle of the body has been given the name of angels because all those particles listen to their Dear Lord's voice and do what they are ordered to do. For example, whatever changes happen in the human body with respect to sickness or health, each particle from these materials moves back and forth according to God's will ... Without believing this organization, God's omniscience cannot be proved nor can his creation function. If every particle does not obey him as an angel how can this whole machine work according to his will.

AḤMAD 1891c: 44

Not unlike Khan's forces of nature, Ahmad's angels are "particles" of a human body. They are no longer supernatural agents of traditional Muslim theology who travel from heaven to earth to convey God's message to human beings. This is established, for example, in his explanation of the various roles of the archangel Gabriel which he explains by appealing to various natural processes:

Regarding revelation (wahi) Gabriel has three jobs. First, when semen falls in a womb for such a person whose nature the all-powerful God because of his kindness, that has nothing to do with human actions, has decided to make revelatory (mulhimana) then he puts the shadow of 
Gabrielic light (nur) on that sperm. Then that person's nature develops a revelatory nature from God and he gets revelatory organs.

AḤMAD 1891c: 84

\subsection{The Nature of the Miracles of Past Prophets}

The Qurān's prophets include Biblical figures such as Adam, Abraham, Moses, Jacob, Joseph, as well as Jesus and Islamic tradition associates all of them with various supernatural events, such as miracles which Allāh granted them in order to support their missions (Alumujali 2014). The Qurān describes a number of such miracles in detail while hinting at many others. Early exegeses of the Qurān (for example, by Ibn Kathir, Yaqubi, Ibn al-Athir and Ibn Ishaq) expanded on these stories. Brannon Wheeler (2002) argues that stories of prophetic miracles played a critical role in the development of a coherent, "more accessible and less piecemeal interpretation of the Qur'ān" (Wheeler 2002: 7).

Given Khan's insistence on God's unchanging law of nature, as mentioned above, he explained all miracles mentioned in the Qur'ān in naturalistic terms. As discussed earlier, he denied that Prophet Muhammad split the moon into two and then rejoined the moonlets back together again. Khan argued that the Qur'anic verse suggesting the splitting of the moon was a prophecy about the end of times and not description of an event that had actually taken place. He also explained away miracles Muslims had traditionally associated with Jesus such as Jesus making clay birds come alive and switching the body with another person just before his crucifixion (Reynolds 2009). Although in Braheen (published 1880-1884), Ahmad had proclaimed his adherence to the traditional Ahl-e-Hadìth views about Jesus' miracles and ascension to heaven, in 1891 , he also downplayed these miracles.

\subsection{Jesus'Miracles}

In Volume 2 of Tafsir published in 1885, Khan comprehensively went through the list of various miracles traditional Muslims had attributed to Jesus and argued that none of them could be proven to have occurred super-naturally from Qurān. When interpreting Qurān 5:110, which Muslims had traditionally interpreted to mean that Jesus created birds out of clay and made them come alive and fly away. Khan argued that this was not the correct interpretation of the Qur'annic verse. He claimed that Muslim exegetes had been engaged in blind following (taqlid) of "incorrect Christian traditions" (Khan 1885: 151). Khan argued that events Qur'ān only describes Jesus' desire to have the claybirds fly but there is no mention in Qur'ān of God accepting Jesus' request and the birds ever actually having flown much less having become alive (Khan 1885: 151). If we believe Khan's claim of being the first Muslim to deny Jesus' 
miracle of making clay-birds alive, then Ahmad must have been the second Muslim to do so. In his book Azala-e-Auham published six years after Khan's publication, Ahmad also denied Jesus miraculous powers, but his explanation was a lot more fanciful:

It is not surprising if the High Lord could have told Jesus about a clay toy that flew like the birds or walked by pressing a key or as a result of blowing on it. Since Jesus, son of Mary, worked with as a carpenter with his father for twenty-two years, and it is clear that carpentry is one of those jobs that increase one's smarts for inventing mechanisms and artifacts ... Even in today's age it is seen that some designers create such birds that talk and travel and move their tails. I've also heard that some birds fly through mechanics. Many such toys are made in Bombay and Calcutta and Europe and America. And new ones are invented every year. Since the Holy Qurān is full of metaphors, these verses can also be interpreted spiritually that clay birds refer those illiterate and ignorant people that Jesus befriended ... and blew the soul of guidance into them that made them take flight.

In addition, it is also possible that such miracles could have taken place through amal-al-tarab i.e., mesmerism in a frivolous way and not for real. Because amal-al-tarab that in the present age is called mesmerism is full of such wonders that those who are fully practiced in it can seemingly bring things to life by pouring the energy of their soul onto those things ... It should be remembered that this practice is not as worthy as commoners think that it is. If this humble servant did not think of this practice as despicable and contemptible then I am strongly hopeful that because of God's blessings I would not have been any inferior than Jesus, son of Mary, in showing such wonders.

Aफ̣MAD 1891a: 309-312

Thus, similar to Khan, Ahmad also claims that Qur'àn does not say that the clay birds ever flew much less became alive. He also presents explanations designed to show that what appears to be a violation of law of nature was not as such. However, unlike Khan who offered a single explanation, Ahmad offers multiple ones. Furthermore, while unlike Khan's rationalization Ahmad's rationalizations cast aspersions on Jesus's spiritual status. Ahmad claimed that Jesus's other miracles of healing the sick and bringing the dead back to life were also done in a 'frivolous way' through the use of mesmerism (Ahmad 1891a: 311). A downside of practicing mesmerism, argued Ahmad, is that one loses one's prophetic power to reform society of its spiritual ills. This he said explained why 
Jesus had "almost failed" to guide people to "God's oneness (tawhīd)" (Ahmad 1891b: 311).

Khan and Ahmad were both motivated by a desire to improve Islam's status with respect to its competitors in South Asia, namely, Evangelical Christianity ushered in by the British colonials and resurgent Hindu movements including the Arya Samaj and the Shuddhi Movement (Jaffrelot 2007). However, they chose two different methods to achieve that end. Khan chose to give Islam a rational makeover to make it appear more at home in the modern scientific world. Ahmad, on the other hand, focussed his primary efforts at critiquing Hinduism and Christianity. This is reflected in how the two employed their rationalizations of Jesus' miracles. While Khan's rationalization is intended to make Islam and the Qur'ān sound more rational, the primary purpose of Ahmad's rationalizations is to diminish Jesus' prophetic status (who he relegates to a magician, using cheap tricks rather than true spiritual insight) relative to the prophets of Islam (including Ahmad himself, alongside Muhammad).

Unlike Khan, Ahmad also claimed that Muhammad had the power to show supernatural miracles because he did not practice mesmerism and therefore had greater spiritual powers. This enabled the Prophet Muhammad to show 'real' miracles such as "splitting of the moon" into two (Ahmad 1891a: 302). Contrary to Khan who denied miracles in principle, whether they were attributed to Muhammad or to Jesus, Ahmad denied Jesus miraculous powers while confirming them for Muhammad. The only exception to this rule is Muhammad's miracle of mirrāj, that is, physical ascension to heaven and flight to visit Jerusalem and to heavens to meet with past prophets such as Jesus. Ahmad denied Muhammad this miracle, the reason for this exception being that admitting Muhammad's physical ascension would have required admitting the possibility of Jesus' miracle of having survived crucifixion by his own physical ascension to heaven, both ascensions being described using the same terms ( $r a f a)$ in the Islamic scriptures.

Through his 1880 publication of the first volume of his Tafsir, Khan may have also become the first Muslim to deny the claim that Jesus survived crucifixion by ascending to heaven. As the excellent review by Gabriel Reynolds (2009) shows, all previous Muslim scholars who had written on the subject had unanimously agreed that God had lifted Jesus to heaven alive to save him from the disgrace of being hanged. Given Khan's stand against all supernatural events, he disagreed with all his predecessors. But instead of simply adopting the position that Jesus had been crucified and had died on the cross, he came up with a novel theory. He argued that because Jesus was hanged on a Friday afternoon, he was only up on the cross for a few hours before being taken down on account of the Sabbath (Khan 1880: 39-40). Even though the 
"Jews requested that his leg bones be broken" the Romans did not do so (Khan 1880: 39). Joseph, who received his body, chose not to bury him. Instead, he covered Jesus in a shroud and hid him in a cave. Khan wrote:

Jesus was taken down from the cross after three or four hours and it is completely possible to believe that he was still alive. At night, he was taken out of the shroud and he secretly stayed under the protection of his disciples. The disciples saw him and met him. And he died later at some unknown location. Undoubtedly, because of the Jewish enmity, he was secretly buried at an unknown location that is unknown to this day. And they popularized the idea that he has been lifted to the heavens.

KHAN 1880: 41

Ten years after the publication of Khan's Tafsir , in January 1891, Ahmad, who had previously professed standard Muslim beliefs about Jesus in Braheen, claimed that God had recently given him divine knowledge about Jesus' survival from the cross. He said, that it had been revealed to him that "they thought that they had killed him on the cross but because they hadn't broken his bones. Thus he was saved because of the support of a faithful and a good man and he passed away after spending the rest of his days" (Ahmad 1891b: 25). A few months later, Ahmad added more details to this account in his book Azala-e-Auham (Ahmad 1891a: 378-386). These details (and even the language used to describe them) sound remarkably similar to those published by Khan a decade earlier, though Ahmad does add a few embellishments of his own. In Ahmad's account Jewish leaders play a critical role. He calls them maulvis, the term used to refer to Muslim clerics in South Asia and argues that they were the ones who asked a reluctant Pontius Pilate for Jesus's crucifixion. He also adds the notion of a dust-storm that resulted in darkness earlier than usual to explain why Jesus was taken down so early and why his leg bones were not broken (Ahmad 1891a: 385). In another point of departure from Khan's version, and similar to his explanation of clay birds, Ahmad claimed that God had revealed the knowledge of Jesus' survival on crucifixion to him through ilham and kashaf (revelations): "I swear to He who holds my life in His hands that that right now and at this instant, in a divine vision (kashaf) the truth has been revealed to me. What I have just written is from the teachings of that True Teacher" (Ahmad 1891a: 376).

Ahmad's use of the term maulvis to refer to Jewish priests seems intentional. It was a part of his argument that he was a Messiah similar to Jesus (misl-emaseeh) and was also being opposed by maulvis of his time just as the original Messiah had been. He argued that because of these the similarities between 
him and Jesus, his coming had fulfilled Prophet Muhammad's prophecy about the second coming of Jesus at the end of times. Jesus had come 1400 years after Moses, and Ahmad had come 1400 years after Muhammad. Muslim 'ulama $\bar{a}^{2}$ had gone astray similar to Jewish priests and thus Islam needed a reformer. The British government in India was benevolent similar to the Roman government in Israel in the time of Jesus.

\section{5}

\section{Prayers}

Khan believed that Islam was more a rational and logical religion than Christianity and Hinduism-Islam's primary competitors in nineteenth century South Asia. The irrational elements (such as supernatural miracle stories) had crept into Islam from other religions. Ridding Islam of the supernatural elements to make it more logical and rational is the best way to demonstrate its superiority. Ahmad's diagnosis of Islam's ills (as he laid it out in Braheen) was very different from that of Khan's. Ahmad believed that Islam's primary distinction from other religions was that it brought humans into a relationship with a living God who listened to their prayers and responded to them. Ahmad claimed that God regularly talked to him and told him of future events. In Braheen, he challenged non-Muslims to visit Qāḍiān and spend a few months in his company to witness these miraculous events, even promising them a payment of 10,00o rupees if they had no supernatural experiences (Aḥmad 1880).

Ahmad criticized Khan for denying miracles shown by Muslims, in particular the Prophet Muhammad. He joined his friend and Ahl-e-Hadīth leader Bațālvī in arguing that Khan was engaged in dangerous bid'a by doing so and mocked him as a 'naturie' who uncritically followed the Western Orientalists in maligning Islam. Ahmad accused Khan of "leading astray a large number of Muslims" and bringing "them to the brink of heresy and atheism by undermining the sanctity of the revelation of prophethood" (Ahmad 1893: 33). Given Ahmad's attempt to establish prayer as a point of distinction for Islam, it is understandable that he was not delighted at Khan's assertions that prayers (Christian or Muslim) do not have any impact on the outcome of an event. In 1893, Ahmad penned Barakat-ud-dua (Blessings of Prayer) in "refutation of the concepts of Sayed Ahmmad Khan Sahib." Aḥmad's basic argument in Barakat was to present incidents from his personal life where he believed that his prayers had been answered by God. He also reissued his challenge from Braheen, inviting those who were skeptical of the power of prayer to come to Qādiān and see it for themselves. He added a personal invitation to Khan: 
stay in my company for a few months. Having been appointed by God and being the bearer of glad tidings, I promise that I will concentrate (in prayer) so that Sayyid Sahib may be satisfied. I do hope that God Almighty will manifest such a sign that Sayyid Sahib's proposed law of nature will be brought to naught in no time.

Aب̣MAD 1893: 22

Khan never acknowledged the existence of Ahmad's 'refutation' much less responded to it. Such was their relationship. The fact that Ahmad acknowledged having read Khan's books prior to 1893 through his refutation leaves the possibility open that he may have read them prior to 1891 when he first published his own rationalistic interpretations of Jesus's crucifixion. Given the unequal power between the two men in 1893, Ahmad was probably able to anticipate Khan's non-response. So he decided to pray for Khan and his followers even without Khan's acceptance of Ahmad's challenge or a visit to Qāḍiān: "God Almighty may wash away this cursed naturalism from the hearts of Muslims, so that no stain of it may be left" (Ahmad 1893: 34). Khan passed away in 1898, and ten years later, Ahmad followed.

The religious movement founded by Aḥmad, known as Jamā'at-e-Aḥmadiyya has been led by a Khalifa since Ahmad's demise. The movement claims millions of adherents in India, Pakistan, East Asia, Western Africa, Europe and North America. Khan today is primarily remembered as an educationalist rather than as a religious reformer. While few people read his Qurānic exegesis, the college he founded in Aligarh continues to educate thousands of Muslim students in Western sciences as do an uncountable number of other schools, colleges, and universities across South Asia. Far fewer Muslims today see Islam and Western science as polar opposites than in the nineteenth century. Thus, both social identity entrepreneurs can be said to have achieved some success in achieving their goals.

\section{Conclusion}

The Aḥmadiyya Muslim Jamā'at with its belief in prophethood for its founder Mirzā Ghulām Aḥmad, has long been considered an enigma by scholars of South Asian Islam. This chapter complements recent attempts to understand various influences on Ahmad's thoughts. It explores the influence of rationalistic reform movement led by Khan. I perform a careful comparison of their writings to explore the similarities and differences and analyse why Ahmad employed rationalistic techniques sometimes but not at other times and why. 
Taken in conjunction with recent work, such as that of Friedman (1992) and Khan (2015) that explains that Ahmad's claims about a high spiritual status were not entirely out of line with those made by Șüfis such as Shaykh Ahmad Sirhindi, and that Ahmad's anti-taqlìd beliefs were not entirely out of line with those of Ahl-e-Hadìth (Upal 2016), I argue here that Ahmad's rationalist beliefs were not entirely out of line with those of Khan's naturalism. Ahmad was certainly unique in his combination of these strands and Ahmadiyya Jamā'at is certainly in a unique position among Islam inspired movements as fiercely clinging to their identity as Muslims while believing in a prophet after Muhammad. Despite these claims or perhaps because of them, Ahmadiyya Muslims are persecuted in many Muslim majority countries around the world. This is especially true in Pakistan where the movement was based until 1984 (it has been based out of London, UK since 1984). Pakistan's constitution was modified twice (in 1974 and 1984) to make propagation and practice of Ahmadiyya beliefs a punishable offense. The anti-Ahmadiyya hostility is not limited to the government but is widespread among Pakistani public. This means that they also face widespread discrimination in the private job market, admissions to educational institutions, as well as in public service.

\section{References}

Ahmad, M.G. 188o. Braheen-e-Aḥmadiyya. Amritsar: Riaz-e-Hind Press.

Ahmad, M.G. 1891a. Azala Aouham. Amritsar: Riaz-e-Hind Press.

Ahmad, M.G. 1891b. Fath-e-Islam. Amritsar: Riaz-e-Hind Press.

Ahmad, M.G. 1891c. Tauzih-e-Maram. Amritsar: Riaz-e-Hind Press.

Allen, C. 2006. God's terrorists: The Wahabi cult and the hidden roots of modern Jihād. Cambridge, UK: Da Capo Press.

Alumujali, H. 2014. "The Relationship between the Prophet Muhammad and the Qurān." Journal of Islamic Studies and Culture. 2:4, 1-5.

Batalavi, M.H. 1891. "Fatawa Ulama-e-Punjab wa Hindustan ba haq Mirzā Ghulām Aḥmad Sakin Qāạiān." Ishat-us-Sunnat-ul-Nabwia. 14: 1-7, 1-208.

Bisati, 2001. Sheikh Ahmad Sirhindi's Thought and Its Impact on the Development of Süfism. PhD Thesis, University of Kashmir, Srinagar, India.

Boyer, P. 1994. The Naturalness of Religious Ideas. Berkley, CA: The University of California Press.

Derajat, A. and A.Y. Hasymsyah. 2019. "Theology Thought of Sir Sayyid Ahmad Khan." IOSR Journal of Humanities and Social Science (IOSR-JHSS). 24(1), 53-59.

Faruqi, S.R. 2017. "From Antiquary to Social Revolutionary: Sir Syed Ahmad Khan and Colonial Experience." In S. Muhammad ed., Sir Syed Ahmad Khan Memorial Lectures. New Delhi: Viva Books Private. 
Friedman, Y. 1992. Prophecy Continuous: Aspects of Ahmadi Religious Thought and Its Medieval Background. New Delhi: Oxford University Press.

Jaffrelot, C. 2007. Hindu Nationalism: A Reader. Princeton, NJ: Princeton University Press.

Khan, A.H. 2015. From Șüfism to Ahmadiyya: A Muslim minority movement in South Asia. Indianapolis, IN: Indiana University Press.

Khan, S.S.A. 1872. Review on Dr. Hunter's Indian Musalmans: Are they bound in conscience to rebel against the Queen? Benaras, India: Medical Hall Press.

Khan, S.S.A. 1880. Tafsìr-ul-Qur'ān wa howa alhuda wal furqan. Vol. 1. Lahore: Rifahe-Aam Steam Press.

Khan, S.S.A. 1959. Maktoobat-e-Sir Syed Volume 1, ed. S.M.I. Panipati. Delhi: Majlist Taraqi-e-Adab.

Lavan, S. 1974. The Ahmadiyya Movement: A history and perspective. New Delhi: Manohar Book Services.

MacGregor, R.J. 2002. "New Sources for the Study of Șūfism in Mamluk Egypt." Bulletin of the School of Oriental and African Studies, University of London. 65:2, 300-322.

Metcalfe, B.D. 1982. Islamic Revival in British India: Deoband, 1860-19oo. Princeton, NJ: Princeton University Press.

Pickthall, M. 1938. The Meaning of the Glorious Koran. Hyderabad-Deccan: Government Central Press.

Powell, A.A. 1993. Muslims and Missionaries in Pre-Mutiny India. Abingdon: Routledge Press.

Reynolds, G.S. 20og. “The Muslim Jesus: Dead or alive?” Bulletin of the School of Oriental and African Studies. 72:2, 237-258.

Robinson, F. 1988. Varieties of South Asian Islam. Warwick: Centre for Research in Ethnic Relations, Research Paper Number 8, University of Warwick.

Robinson, F. 200o. Islam and Muslim History in South Asia. Delhi: Oxford University Press.

Sanyal, U. 1996. Devotional Islam and Politics in British India: Aḥmad Riza Khan Barelwi and His Movement, 1870-1920. Delhi: Oxford University Press.

Sedgwick, M. 200o. "Sects in the Islamic World." Nova Religio. 3:2, 195-240.

Upal, M.A. 2017. Moderate Fundamentalists: Aḥmadiyya Muslim Jamā'at in the lens of cognitive science of religion. Warsaw: DeGruyter.

Walter, H.A. 1918. The Ahmadiya Movement. New York: Oxford University Press.

Wheeler, B. 2002. Prophets in the Qur'ān: An Introduction to the Qur'ān and Muslim Exegesis. London: Continuum. 